\title{
Improving Educational Quality through Optimizing the Potential of Educational Institutions in Indonesia
}

\author{
Feiby Ismail $^{1 *}$,Abdul Muis Daeng Pawero ${ }^{2}$, Mardan Umar $^{3}$ \\ ${ }^{1}$ Islamic Educational Management Departement, Faculty of Tarbiyah and Teacher Study \\ IAIN Manado, Indonesia \\ ${ }^{2}$ Islamic Educational Management Departement, Faculty of Tarbiyah and Teacher Study \\ IAIN Manado, Indonesia \\ ${ }^{3}$ Faculty of Social Sciences, Manado State University, Indonesia \\ ${ }^{*}$ Corresponding author: \\ Email: feibyismail@iain-manado.ac.id
}

\begin{abstract}
.
The quality of education in an educational institution will be greatly influenced by the potential of educational institutions and the governance system. The existing potential must be optimized to support quality improvement. Likewise, the education governance system will develop well when it is implemented through a good system by professional managers. The system has been designed in detail by the government which was stipulated by the Minister of National Education Regulation No. 19 of 2007 concerning "Education Management Standards by Primary and Secondary Education Units". This regulation was prepared by the government to regulate a good, balanced and sustainable governance system.The problem is determined to what extentthe ability of educational institutions to optimize the potential of the institution and optimizing inputs, processes, outputs and outcomes, starting from planning, organizing, actuiting, and controlling. This paper will discuss the improving educational quality through optimizing the potential of educational institutions in Indonesia in order to achieve shared ideals for a better educational future.
\end{abstract}

Keywords:Education, quality, Educational Policy, management.

\section{INTRODUCTION}

Sallis states that quality is something that is defined by customers. So that customer satisfaction is the main thing, so that quality is determined to what extent it is able to satisfy customer needs and desires [1].This statement shows that customer satisfaction is the main thing in quality problems. Regarding the quality of education, educational institutions must prioritize student satisfaction and education stakeholders. So that Umar and Ismail stated that quality must be the top priority of education in all educational institutions [2].

The involvement of all education components is one of the requirements for quality education because education can only achieve quality if it involves and optimizes all the potential of the school [3]. On the other hand, a collaborative relationship needs to be established between educational institutions and the government in an effort to develop and optimize all the potential of educational 
institutions. The main objective is for the quality of education to increase from time to time. as stated by Sampul, et.al. thatcollaboration between school elements and collaboration with the government and related agencies is very important to guarantee the quality of education [4].

The fast informatization process due to technological advances has made the horizon of life in the world even wider and at the same time makes the earth seem to be shrinking even more. This means that various problems in human life become global problems or at least cannot be separated from the influence of events in other parts of the world, be it political, economic, or social issues. The social solidarity of mankind is getting stronger. This means that human concern for each other is increasingly the duty of every human being, the government and the national education system. Education has the task of developing awareness of the responsibility of every citizen for the continuation of his life, not only to the community and state, but also to humanity. Therefore, education is one of the supports towards this global awareness[5].

According to Article 1 of the National Education System Law Number 20 of 2003, national education functions to develop capabilities and form a dignified national character and civilization in order to educate the nation's life, aiming at developing the potential of students to become faithful and fearful of God Almighty. , have noble character, healthy, knowledgeable, competent, creative, independent, and become democratic and responsible citizens[6].This means that education is a guide, guide and direction for students so that they can grow up according to their true potential and self-concept, so that they can grow, compete and maintain their lives in a future full of challenges and changes.

Based on the definition of education as described above, it can be understood that education aims to develop abilities and shape the character and civilization of a nation with dignity.However, on the other hand, whether the quality of education is bad or not will be greatly influenced by the governance system. The education governance system will develop well when it is implemented through a good system by clean and professional managers. The system has been designed in detail by the government which was stipulated by the Minister of National Education Regulation No. 19 of 2007 concerning "Education Management Standards by Primary and Secondary Education Units". This Regulation of the Minister of Educationwas prepared by the government to regulate a good, balanced and sustainable governance system.

The education governance includes; 1) Program Planning; 2) Implementation of Work Programs; 3) Monitoring and Evaluation; 4) School/Madrasah Leadership; 5) Management Information System; 6) Special Assessment. At the planning level, programs organized by educational institutions must reflect the existence of a vision, mission, goals and work plans so that they can assist the government in achieving national education goals. In order to examine planning as an effort to formulate 
educational policies to face challenges in the future, this paper will discuss new directions of education planning and their implications for education policy.

\section{METHODS}

This research is a library research or literature research, namely the type of research conducted withread books or magazines and other data sources forcollect data from various literature, both library andin other places [7]. This research is a literature review by combining state laws and regulations regarding education, sources of books and journals as well as studies of previous research results. The study conducted a content analysis of content related to education. Therefore, this study uses content analysis techniques to discuss in depth about education planning and its implications for education policy in Indonesia.

According to Guba and Lincoln (Komariah and Satori, 2009: 157), content analysis is a process that is directed at generalizing and discussing the manifested content. In this context, researchers discuss and generalize on educational planning in determining the direction of national education policies [8].

\section{RESULT AND DISCUSSION}

Quality aims to provide satisfaction to customers. Fattah (2012:2) explains that quality is the ability of a product or service that can meet needs or expectations, customer satisfaction, which in education is grouped into two internal and external customers. customer. Internal customers are students or students as learners, and external customers are the community or the world of industry. this means that customer satisfaction is an important point in quality [9].

As in general human life, most people want to pursue a quality life throughout their life. Quality life is an important factor for a person to live a happy, safe and satisfying life. Therefore, to obtain a quality of life, humans must also have a standard of living. Achieving a quality standard of living, allows one to live a human life. Educational institutions are places to improve the quality of life. Therefore, educational institutions must also be of high quality, both in terms of curriculum implementation, teachers who teach, and the environment in which students learn [10].

However, to achieve quality education requires a lot of energy, both from the government and society. Moreover, the problem of education is indeed so complex. In addition to the problem of education equality which is a gradual and continuous process, there are two impacts of the accelerated development of the education sector, namely the problem of the quality of education that is recognized as still lacking (compare, for example, with the quality of education in neighboring countries such as Singapore and Malaysia), and the relevance of educational outcomes to demands. development will be the availability of a skilled workforce in sufficient numbers to fill open job opportunities or open new jobs. Education in Indonesia is becoming increasingly worrisome with a symptom of the increasing number of unemployed or 
underemployed high school and tertiary school graduates. For example, the Central Association of Higher Education Communication Studies (Aspikom) said that through the data collected, the largest number of contributors to unemployment in Indonesia came from scholars. In fact, the unemployment rate of university graduates in Indonesia has increased by 25 percent from 2017 to 2019 [11]. Not to mention, for example, when discussing the morality crisis of students which can be seen from the prevalence of promiscuity, fights between students, cheating culture, and various other problems.

On the other hand, the quality of educational life is also related to the competence of educational institutions in terms of library accommodation to meet various knowledge needs, adequate infrastructure, and programs that direct the social goals of educational institutions. Educational institutions still have to focus on the cognitive domains of students, as well as pay attention to and provide assessments on affective aspects. This is because several studies that show student success are mostly due to affective factors [12].

No matter how complex the problems and challenges of the world of education in Indonesia, an important point that needs to be emphasized first is that educational institutions are not just implementers of national policies or the ministry of education, or the preservation of values that exist in a society. Educational institutions, more than that, must be seen as one of the social forces that contribute to shape, style and direction in the future life of society. So educational planning in educational institutions must be the main foundation of Indonesia's education building in the future.

With the reason of improving the quality and standard of education, various efforts and regulations were made to uniform national education. Based on the assumptions of efficiency and uniformity, it is endeavored to arrange national education through standards (one of which is the education process standard) as well as various regulations that guarantee the uniformity of a system. Various methods are implemented by applying the principles of Total Quality Management (TQM) in the field of education to achieve the desired quality of education.

Various standardization efforts are developed to uniform the quality of education throughout the country. Indeed, the results of the systematization of education, from a certain point of view, show encouraging results such as accelerating the achievement of quantitative educational targets. However, many negative results were born in this systematization effort. The death of initiative, loss of critical thinking and various other negative influences have been born from a very rigid education system that is governed by the desire to achieve national uniformity. So in order to catch up and even eliminate backwardness, the formulation of education policies must be oriented towards the academic development of students without neglecting the diversity elements that exist in the life of Indonesian society.

Discussion of improving the quality of education should emphasize planning, processes, outputs and outcomes for educational institutions.Therefore, there are 
several things that need to be considered in improving the quality of education, including: curriculum, human resources, the learning process which includes learning methods and media, and evaluation and cannot be ignored, the importance of educational facilities, facilities and infrastructure.

In the context of education quality, what is meant by customers are learners or students. So the extent to which educational institutions or educational institutions are able to provide maximum service to students from entry to graduation. Schools or madrasahs must provide all the tools to satisfy students and later graduate users or stakeholders. The quality of education cannot be separated from the components:

a. Students; readiness and motivation to learn.

b. Teacher; professional ability, work morale (personal ability).

c. Curriculum; content relevance and operationalization of the learning process.

d. Facilities and infrastructure; adequacy and effectiveness in supporting the learning process.

e. Public; parents, graduate and college users. Participation in the development of school research programs [13].

Based on the previous description, educational institutions must optimize all their potential such as human resources and available facilities. To develop human resources, it is necessary to carry out education and training for teachers and administrative staff to increase knowledge related to education and learning as well as education management as a whole. In addition, optimizing the use of facilities and infrastructure for educational institutions by utilizing existing and developing technology. In addition, adjustments between the needs and demands of the times are of concern to schools so that students and stakeholders get satisfaction from the resulting educational output.

Quality is a dynamic condition related to products, services, people, processes, environments that meet or exceed expectations. Likewise, in terms of cooperation, each component related to the successful achievement of educational goals is very important to improve the quality of education. Not only attention, but more than that, requires participation and involvement in the educational process.

One of the most important things is strategic planning which aims to analyze the extent to which strategic objectives and action plans are deployed, change and can be measured. Process management also needs attention to focus on the core competencies of the organization and work systems, and knowing how to design, manage and improve key processes to achieve organizational success and sustainability.

\section{CONCLUSION}

In accordance with the study described before, several things can be concluded, namely: the quality of education is an important issue that must be the focus of attention of education in Indonesia. Optimizing all potential in the educational environment is one of the requirements for improving the quality of education with the 
growth of a good quality culture. Therefore, educational institutions in Indonesia must pay attention to the suitability of the curriculum with the times, the provision of qualified human resources to have a positive impact in the educational process, then the availability of educational facilities and infrastructure must be met to meet customer satisfaction, in this case students, society and stakeholders more broadly.

\section{REFERENCES}

[1] Sallis. E. Total Quality Management in Education, 2012, Yogyakarta: IRCiSoD.

[2] Umar, M, dan Ismail, F. Peningkatan Mutu Lembaga Pendidikan Islam(Tinjauan Konsep Mutu Edward Deming dan Joseph Juran),Jurnal Pendidikan Islam Iqra' Vol. 11 Nomor 2 Tahun 2017, Manado: FTIK IAIN Manado.

[3] Ismail, F. Manajemen Berbasis Sekolah: Solusi Peningkatan Kualitas Pendidikan. Jurnal Pendidikan Islam Iqra', 2(2), 1-17. 2008, Manado: FTIK IAIN Manado.

[4]Sampul, D. et.al., Implementation of the Internal Quality Assurance Process: Quality Mapping Analysis at State Senior High Schoolin Tomohon City, North Sulawesi, Indonesia, IJORER : International Journal of Recent Educational Education, Vol. 1, No. 2, July2020 : 124-133.

[5] T.D.E., Ellong, dan Abdul Muis Daeng Pawero, Analisis Kritis Tentang Kebijakan Standar Proses Pendidikan Di Sekolah/Madrasah, Proceeding; The 1st Annual Conference on Islamic Education Management, no. 2 (2018), 847-852.

[6] Republik Indonesia, Undang-undang R.I, Nomor 20 tahun 2003 tentang Sistem Pendidikan Nasional, Pasal.1

[7] Mahmud, Metode Penelitian Pendidikan, CV Pustaka Setia, Bandung, 2011, hlm. 31.

[8] Satori, D. dan Komariah, A., Metodologi Penelitian Kualitatif, 2009, Bandung: Alfabeta, h. 157.

[9] Fattah, N. Landasan Manajemen Pendidikan,2012. Bandung: PT. Remaja Rosdakarya

[10]Elitok Kesici, Ayşe, dan Veysel Karani Ceylan, Quality of school life in Turkey, Finland and South Korea, International Journal of Evaluation and Research in Education (IJERE), Vol. 9, No. 1, March 2020, pp. 100-108.

[11]Ega Alfreda, "Lulusan Sarjana Menjadi Penyumbang Pengangguran Terbanyak di Indonsia".https://jakarta.tribunnews.com/2019/11/27/lulusan-sarjana-menjadipenyumbang-pengangguran-terbanyak-di-indonesia/

[12]N. Park, Life satisfaction among Korean children and youth: A developmental perspective, School Psychology International, vol. 26, 2005, pp. 209-223.

[13]Asmuni, Konsep Mutu Dan Total Quality Manajement (TQM)Dalam Dunia Pendidikan, Jurnal TA'DIB, Vol. XVIII, No. 01, Edisi Juni 2013, h.16-42. 